University of Nebraska - Lincoln

DigitalCommons@University of Nebraska - Lincoln

Biological Systems Engineering: Papers and

Publications

Biological Systems Engineering

1994

\title{
Long Term Tillage Effects on Grain Yield and Soil Properties in a Soybean/Grain Sorghum Rotation
}

\author{
Elbert C. Dickey \\ University of Nebraska at Lincoln, edickey1@unl.edu \\ Paul J. Jasa \\ University of Nebraska at Lincoln, pjasa1@unl.edu \\ Robert Grisso \\ Virginia Polytechnic Institute and State University, rgrisso@vt.edu
}

Follow this and additional works at: https://digitalcommons.unl.edu/biosysengfacpub

Part of the Biological Engineering Commons

Dickey, Elbert C.; Jasa, Paul J.; and Grisso, Robert, "Long Term Tillage Effects on Grain Yield and Soil Properties in a Soybean/Grain Sorghum Rotation" (1994). Biological Systems Engineering: Papers and Publications. 260.

https://digitalcommons.unl.edu/biosysengfacpub/260

This Article is brought to you for free and open access by the Biological Systems Engineering at DigitalCommons@University of Nebraska - Lincoln. It has been accepted for inclusion in Biological Systems Engineering: Papers and Publications by an authorized administrator of DigitalCommons@University of Nebraska Lincoln. 


\title{
Long Term Tillage Effects on Grain Yield and Soil Properties in a Soybean/Grain Sorghum Rotation
}

\author{
Elbert C. Dickey, Paul J. Jasa, Robert D. Grisso*
}

In Nebraska, early adopters of conservation tillage, especially those using no-till planting, had some concerns regarding planter performance, early season weed control, and possible yield reductions. Selected tillage and planting systems were used long term to evaluate effects on soybean [Glycine max (L.) Merr.] and grain sorghum [Sorghum bicolor (L.) Moench] yield, soil properties, and residue cover in a nonirrigated rotation. The six tillage and planting systems selected for evaluation were: no-till, no-till with row-crop cultivation, disk, double disk, chisel, and plow. In 1981, two sets of field plots were established near Lincoln, NE, on a Sharpsburg silty clay loam (fine, montmorillonitic, mesic Typic Argiudolls) so that both crops could be evaluated each year. Measurements were not taken until completion of one crop rotation cycle. After this cycle, for the first $3 \mathrm{yr}$ of yield measurements, no differences occurred in grain yield among the tillage and planting systems. After five additional years, differences in yield were measured, with no-till tending to have the greatest yield for both crops. Row-crop cultivation of no-till soybean did not result in any measurable yield differences, but for grain sorghum, row-crop cultivation resulted in an average yield decrease of 6 bu/acre. Soil organic matter tended to be greatest for the continuous no-till system and lowest for the plow system. The plow system had slightly less penetration resistance within the 4- to 8-in. depth than the other treatments, whereas, the double-disk system

Biological Systems Engineering Dep., L.W. Chase Hall, University of Nebraska, Lincoln, NE 68583-0726. Published as Univ. of Nebraska Agric. Res. Div. Journal Series no. 10125 . ${ }^{*}$ Corresponding author.

Published in J. Prod. Agric. 7:465-470 (1994). was slightly greater within the 2- to 6-in. depth. Draft and power requirements for planting in the selected tillage and planting systems were not different. The major difference among the tillage and planting systems was residue cover remaining after planting. No-till had the most residue cover, but there was no appreciable accumulation of residue over the $10 \mathrm{yr}$ of continuous use of the tillage and planting systems. For the last $5 \mathrm{yr}$, no-till tended to have the greatest yield for both crops. Thus, for the soil and conditions evaluated, no-till yields were as good as the other systems during early years, and were better after $5 \mathrm{yr}$ of continuous use. Thus, producers adopting no-till and other residue management practices have the opportunity to enhance profitability because of the same or greater yields and reduced production costs by eliminating tillage operations.

$T$ ILLAGE OPTIONS available to farmers have proliferated in recent years due to the availability of reliable chemical weed control, new tillage and planting designs, desire to reduce production inputs and costs, and an increased emphasis on soil and water conservation. Conservation tillage, which leaves more than $30 \%$ of the soil surface covered with crop residue, is one of the most effective and least costly methods of reducing soil erosion (Laflen et al., 1980; Dickey et al., 1985; Siemens and Oschwald, 1978) as well as conserving labor, fuel, and soil moisture (Dickey et al., 1991a).

The type and amount of crop residue has a dramatic effect on soil erosion. According to Dickey et al. (1985), 
immediately following harvest, crop residue will cover about $90 \%$ of the soil surface. Soybean residue, however, is fragile and easily destroyed by tillage (Erbach, 1982). Dickey et al. (1985) and Gregory (1982) showed that following equivalent tillage operations, the residue cover was about $40 \%$ less with soybean than with corn (Zea mays L.). Dickey et al. (1985) showed that soil loss was always greater following soybean than corn for five tillage treatments. When averaged across the five tillage treatments, erosion following soybean was $44 \%$ greater than corn on a silty clay loam and more than 3.5 times greater on a silt loam soil. Similarly, Siemens and Oschwald (1978) reported soil losses about three times greater following soybean than corn.

The affect of conservation tillage practices on grain yields depends strongly upon soil and climatic conditions. Power et al. (1986) and Wilhelm et al. (1986) have shown that conservation tillage reduced runoff and evaporative losses of water, which may lead to increased yields when water deficits limit crop growth. In long-term yield studies in northern Ohio, Dick and van Doren (1985) reported greater yields from no-till than from moldboard-plow treatments for a well drained soil with 2 to $5 \%$ slopes. Al-Darby and Lowery (1986) reported greater corn yields from no-till in a loamy sand in Wisconsin, and little influence of tillage system on corn yield for a silt loam soil. In a well-drained soil in northern Indiana, continuous corn yields from chisel-plow, no-till, and moldboard-plow treatments were the same but a till-plant system yielded slightly less (Griffith and Mannering, 1985).

In poorly drained soils, where excess water often limits crop development, reduced tillage could lead to yield reductions. For example, Dick and van Doren (1985) reported lower continuous corn yields from no-till than from a moldboard plow system when grown on poorly drained soil in northern Ohio. Erbach (1982) reported similar findings for continuous corn in Iowa, but yields in a corn-soybean rotation were not affected by tillage system. McIsaac et al. (1990) reported 9-yr average yields of corn and soybean in rotation on a soil with poor internal drainage, using six tillage treatments. Yields for both crops were less for the no-till system than other tillage practices.

Doran et al. (1984) showed grain sorghum tolerated water and heat stress better than corn or soybean. Under no-till, however, grain sorghum yields were unaffected by residue removed, probably because poor plant stands occurred with surface residue. Grain sorghum had the smallest seeds of the three crops observed (corn, soybean, and grain sorghum) and had more difficulty with plant establishment under no-till at 100 and $150 \%$ residue rates. McGregor and Mutchler (1992) showed yields for grain sorghum under no-till was the greatest of four tillage systems evaluated. In addition, deep cultivation for ridge building reduced grain yields.

West et al. (1991) used simulated rainfall to compare soil losses for no-till and conventional tillage methods on grain sorghum sites. On severely eroded landscapes in the southern Piedmont of Georgia, grain sorghum residue was more effective in reducing soil losses than soybean residue. Gilley et al. (1986) reported substantial reductions in soil erosion from simulated rainfall on small amounts
Table 1. Operations for the tillage and planting systems evaluated.

\begin{tabular}{|c|c|c|c|c|c|c|}
\hline \multirow[b]{2}{*}{ Operations } & \multicolumn{6}{|c|}{ Tillage and planting system } \\
\hline & No-till & $\begin{array}{c}\text { No-till w/ } \\
\text { cultivation }\end{array}$ & Disk & $\begin{array}{c}\text { Double- } \\
\text { disk }\end{array}$ & Chisel & Plow \\
\hline $\begin{array}{l}\text { Shred stalks (fall) } \dagger \\
\text { Fall moldboard plow } \\
\text { Fall chisel plow }\end{array}$ & & & & & $\mathbf{x}$ & $\begin{array}{l}\mathbf{X} \\
\mathbf{X}\end{array}$ \\
\hline Knife apply $\mathrm{NH}_{3} \ddagger$ & $\mathrm{X}$ & $\mathrm{x}$ & $\mathrm{X}$ & $\mathrm{X}$ & $\mathrm{x}$ & $\mathbf{X}$ \\
\hline $\begin{array}{l}\text { Apply herbicide } \\
\text { Disk }\end{array}$ & $\mathrm{X}$ & $\mathrm{X}$ & $\mathrm{X}$ & $\begin{array}{l}\mathrm{X} \\
\mathrm{X}\end{array}$ & $\mathrm{X}$ & $\begin{array}{l}\mathbf{X} \\
\mathbf{X}\end{array}$ \\
\hline Disk & & & $\mathrm{X}$ & $\mathrm{X}$ & $\mathbf{X}$ & $\mathrm{X}$ \\
\hline Plant & $\mathrm{X}$ & $\mathrm{X}$ & $\mathbf{X}$ & $X$ & $\mathbf{X}$ & $\mathbf{X}$ \\
\hline Apply herbicide & $\mathrm{X}$ & $\mathrm{X}$ & $\mathrm{X}$ & $\mathrm{X}$ & $\mathrm{X}$ & $\mathbf{X}$ \\
\hline Crop cultivate & & $\mathrm{X}$ & $\mathrm{X}$ & $\mathrm{X}$ & $\mathbf{X}$ & $\mathbf{X}$ \\
\hline
\end{tabular}

† Conducted on the grain sorghum residue only, before planting soybean. $¥$ Conducted before planting grain sorghum only.

of grain sorghum residue. McGregor and Mutchler (1992) measured soil losses from four tillage practices used in grain sorghum production. They showed that no-till was the most effective erosion control method and reduced-till was more effective than ridge-till.

Continuous use of no-till has created concern regarding soil compaction and reduced yields. Bauder et al. (1981) showed that no-till had the greatest soil density, highest soil resistance to cone penetration and least soil porosity when compared with other tillage systems after $10 \mathrm{yr}$ of use on a clay loam soil. Similar results from Dickey et al. (1983) showed that continuous no-till had the highest cone-index values and reduced corn yields on a silty clay loam that tended to be poorly drained. They also showed that the use of chisel plow and disk tillage systems following $3 \mathrm{yr}$ of no-till did not result in a yield increase compared with continuous no-till.

In Nebraska, interest in conservation tillage and other reduced tillage systems began to increase in the early 1980s. Research results concerning conservation tillage were often conflicting and varied depending on production management, rainfall, geographic location, and study duration. In addition, the adoption of conservation tillage practices were slowed by both tradition and lack of experience. Farmer concerns about possible yield decreases, weed pressure, fertilizer placement, equipment performance, and soil responses to fewer tillage operations delayed implementation of conservation tillage methods (Dickey et al., 1991a). Information was available to address these concerns for reduced tillage corn production in semi-humid areas similar to Nebraska. Limited information was available, however, for other crops. Therefore, the effect of reduced tillage on soybean and grain sorghum production in a nonirrigated rotation was evaluated. The goal was to gain management experience and evaluate crop yield, soil properties, and residue cover in long term study and use this information to strengthen conservation tillage educational programs (Dickey et al., 1991a).

\section{MATERIALS AND METHODS}

Research was conducted at the University of Nebraska Rogers Memorial Farm near Lincoln. Two sets of nonirrigated plots, Set $\mathrm{A}$ and Set $\mathrm{B}$, about $0.5 \mathrm{mi}$ apart, were established in 1981 such that grain sorghum and soybean would be grown in annual rotation between sets. In odd numbered years, soybean was grown on Set $\mathrm{A}$ and grain 
Table 2. Grain yield for the first 3 yr of measurement.

\begin{tabular}{lccr}
\hline & \multicolumn{2}{c}{ Percentage of annual mean yield, \% } \\
\cline { 2 - 4 } Tillage and planting system & 1983 & 1984 & 1985 \\
\hline Soybean & & & \\
\hline No-till & $96 \ddagger$ & 108 & 98 \\
No-till w/cultivation & 96 & 102 & 104 \\
Disk & 92 & 105 & 93 \\
Double-disk & 103 & 93 & 106 \\
Chisel & 100 & 100 & 103 \\
Plow & 114 & 92 & 97 \\
Annual mean yield, bu/acre & 31 & 30 & 35 \\
Grain sorghum & & & \\
No-till & $104 \mathrm{~b} \dagger$ & 98 & 103 \\
No-till w/cultivation & $90 \mathrm{a}$ & 103 & 101 \\
Disk & $99 \mathrm{~b}$ & 94 & 101 \\
Double-disk & $100 \mathrm{~b}$ & 98 & 95 \\
Chisel & $103 \mathrm{~b}$ & 103 & 99 \\
Plow & $104 \mathrm{~b}$ & 103 & 101 \\
Annual mean yield, bu/acre & 96 & 104 & 98 \\
\hline
\end{tabular}

$\dagger$ Means followed by the same letter in a column do not differ significantly at the $P=0.10$ level.

$\ddagger$ Columns without letters had no significant differences.

sorghum was on Set B. The soil type was a Sharpsburg silty clay loam (USDA-SCS, 1980). Individual tillage and planting system treatments were arranged in plots $30 \mathrm{ft}$ wide ( 12 rows spaced 30 -in. apart) by $75 \mathrm{ft}$ long. The plots were randomized and replicated three times within each set. Six tillage and planting systems were selected for evaluation: no-till, no-till with row-crop cultivation, disk, double-disk, chisel, and plow. Selection of systems was based on a survey of tillage and planting systems being used in Nebraska (Dickey and Rider, 1980). This paper summarizes the crop yields and other measurements taken over $8 \mathrm{yr}$, ending $10 \mathrm{yr}$ after plot establishment.

Full-sized field equipment (six-row) was used throughout the project. The same moldboard plow, chisel plow, and tandem disk were used each year. Because of the project duration, the stalk shredder, planter, fertilizer applicator, sprayer, and row-crop cultivator were not constant from year to year, but were the same within a given year. The equipment was not readjusted when going from treatment to treatment. Typical operating depths and speeds were used every year. Operations within each tillage and planting system are listed in Table 1. Unless otherwise noted, all field operations were performed in the spring.

No insecticides were used or needed in any year. Anhydrous ammonia was preplant applied on the grain sorghum production areas at the same rate for all treatments within a year, between 70 and $90 \mathrm{lb} / \mathrm{acre}$, depending on the spring soil moisture and the outlook for rain. According to soil test results, no additional plant nutrients were required. Seeding rates ranged from 70000 to 120 000 seeds/acre for grain sorghum and from 120000 to 180000 seeds/acre for soybean, again depending on moisture, but at the same rate for all treatments within a year. Typical planting dates for grain sorghum were between 15 and 30 May and for soybean were between 5 and 20 May. Generally, there were no differences in plant stands observed between tillage treatments, but in years with dry spring weather, the no-till stands appeared more uniform.

Grain yield measurements began in 1983, after the completion of one complete crop rotation cycle. The full
Table 3. Grain yield for the last 5 yr of measurement.

\begin{tabular}{|c|c|c|c|c|c|}
\hline \multirow{2}{*}{$\begin{array}{c}\text { Tillage and } \\
\text { planting system }\end{array}$} & \multicolumn{5}{|c|}{ Percentage of annual mean yield, $\%$} \\
\hline & 1986 & 1987 & 1988 & 1989 & 1990 \\
\hline \multicolumn{6}{|l|}{ Soybean } \\
\hline $\begin{array}{l}\text { No-till } \\
\text { No-till w/cultivation } \\
\text { Disk } \\
\text { Double-disk } \\
\text { Chisel } \\
\text { Plow }\end{array}$ & $\begin{array}{c}103 \mathrm{ab} \dagger \\
107 \mathrm{a} \\
98 \mathrm{~b} \\
97 \mathrm{~b} \\
99 \mathrm{~b} \\
97 \mathrm{~b}\end{array}$ & $\begin{array}{c}104 a \\
101 a b \\
99 a b c \\
101 a b \\
96 c \\
98 b c\end{array}$ & $\begin{array}{c}102 \mathrm{a} \\
105 \mathrm{ab} \\
101 \mathrm{ab} \\
98 \mathrm{~b} \\
100 \mathrm{ab} \\
94 \mathrm{~b}\end{array}$ & $\begin{array}{l}114 \mathrm{a} \\
105 \mathrm{ab} \\
99 \mathrm{bc} \\
99 \mathrm{bc} \\
94 \mathrm{bc} \\
89 \mathrm{c}\end{array}$ & $\begin{array}{r}102 a \\
103 a \\
103 a \\
99 a \\
102 a \\
91 b\end{array}$ \\
\hline Annual mean yield, bu/acre & 53 & 51 & 36 & 43 & 41 \\
\hline \multicolumn{6}{|l|}{ Grain sorghum } \\
\hline $\begin{array}{l}\text { No-till } \\
\text { No-till w/cultivation } \\
\text { Disk } \\
\text { Double-disk } \\
\text { Chisel } \\
\text { Plow }\end{array}$ & $\begin{array}{r}100 \ddagger \\
100 \\
98 \\
99 \\
100 \\
102\end{array}$ & $\begin{array}{c}105 \mathrm{a} \\
100 \mathrm{~b} \\
97 \mathrm{~b} \\
101 \mathrm{ab} \\
99 \mathrm{~b} \\
99 \mathrm{~b}\end{array}$ & $\begin{array}{r}107 \\
102 \\
96 \\
100 \\
100 \\
96\end{array}$ & $\begin{array}{l}106 \mathrm{a} \\
100 \mathrm{bc} \\
103 \mathrm{ab} \\
96 \mathrm{~cd} \\
101 \mathrm{bc} \\
93 \mathrm{~d}\end{array}$ & $\begin{array}{r}107 a \\
105 a \\
101 a \\
101 a \\
99 a \\
89 b\end{array}$ \\
\hline Annual mean yield, bu/acre & 149 & 128 & 134 & 106 & 136 \\
\hline
\end{tabular}

† Means followed by the same letter in a column do not differ significantly at the $P=0.10$ level.

‡ Columns without letters had no significant differences.

plot was combine harvested and the grain was weighed with a weigh wagon. Grain yield was corrected to $14 \%$ moisture content for soybean and $15.5 \%$ for grain sorghum.

Prior to 1984, the weed control program was a burndown herbicide combined with residual herbicides applied at planting. At that time, this was the typical weed control program used in conservation tillage. Nebraska producers, however, complained of no-till weed control failures during soybean and grain sorghum production. These failures seemed to be caused by: (i) competition of early season weed growth and the crop for limited soil moisture; and (ii) a lack of rainfall to adequately incorporate and activate the residual herbicide.

Based on these observations, timing of the herbicide application to reduce weed growth before planting was changed in 1984. Records indicated that the greatest chance of receiving adequate rainfall for incorporation occurred before the end of April. Thus, mid-April was targeted for herbicide application. Since most weed seeds had not germinated at this time, the need for a burndown herbicide was eliminated. In 1986, to help assure full-season weed control, the mid-April application was reduced to a two-thirds rate application, with the remaining one-third applied at planting time in mid-May. From that point forward, this split application was used. Although weed counts were not taken, no appreciable weed pressure was observed in these plots after the new program was initiated.

Products used in the herbicide program varied from year to year to address specific weather and weed problems. In recent years, atrazine and Dual (metolachlor) were used for grain sorghum and Sencor (metribuzin) and Dual or Prowl (pendimethalin) were used for soybean. Often, 2,4-D LV Ester was used with the first herbicide application to control early emerging broadleaf weeds and winter annuals. Total application rate of the herbicides was usually at or below suggested label rates for tilled soils. In a given year, the same herbicide program was used on all tillage and planting systems for each crop, because the pesticide label does not distinguish between tillage and planting systems. 
Table 4. Soil organic matter as measured in two sets of plots in 1990.

\begin{tabular}{lll}
\hline Tillage and planting system & Set A & Set B \\
\hline & & \\
0- to 4-in. depth & & \\
\hline No-till & $3.4 \mathrm{ab} \dagger$ & $3.2 \mathrm{a}$ \\
No-till w/cultivation & $3.7 \mathrm{a}$ & $3.1 \mathrm{a}$ \\
Disk & $3.4 \mathrm{ab}$ & $3.2 \mathrm{a}$ \\
Double-disk & $3.3 \mathrm{bc}$ & $3.1 \mathrm{a}$ \\
Chisel & $3.2 \mathrm{bc}$ & $3.0 \mathrm{ab}$ \\
Plow & $3.0 \mathrm{c}$ & $2.8 \mathrm{~b}$ \\
0- to 8-in. depth & & \\
No-till & $3.1 \mathrm{ab}$ & $2.9 \ddagger$ \\
No-till w/cultivation & $3.3 \mathrm{a}$ & 2.7 \\
Disk & $3.1 \mathrm{ab}$ & 2.9 \\
Double-disk & $3.0 \mathrm{ab}$ & 2.7 \\
Chisel & $2.9 \mathrm{~b}$ & 2.7 \\
Plow & $2.9 \mathrm{~b}$ & 2.7 \\
\hline
\end{tabular}

† Means followed by the same letter in a column do not differ significantly at the $P=0.10$ level.

$\ddagger$ Columns without letters had no significant differences.

Soil samples were taken in the fall of 1990 for soil organic matter determination. A hand probe was used in each plot to take six, 1-in. diameter cores to a depth of 8 in. Each soil core was divided into two subsamples, representing 0 - to 4 -in. and 4 - to 8 -in. depths. The six subsamples for each depth were combined into a single sample. The two samples from each plot, representing the two depths, were analyzed by the University of Nebraska Soil Testing Lab using standard procedures. The soil organic matter results from the two depths were averaged to obtain a 0 - to 8 -in. value.

The penetration resistance of the soil was measured using a tractor mounted soil cone penetrometer in the spring of 1990 when the soybean crop was approximately 6 in. tall. The penetrometer used a load-cell, a depth-position indicator, and a data logger. Measurements, according to procedures outlined in ASAE Standard S313.1 (ASAE, 1983), were taken in the row, to a depth of 16 in. when the soil moisture was at or near field capacity. Approximately 48 readings were taken during the 16-in. penetration. For analysis, the five or six readings that occurred in each 2 -in. depth increment were averaged. Soil samples were also taken in each plot to document the soil moisture content at the time of penetration resistance measurements.

Planter draft and travel speed were measured during the 1988 and 1989 seasons. A portable data acquisition system, using a laptop computer developed by Lackas et al. (1991) was used with a three point hitch mounted drawbar dynamometer and a ground wheel speed sensor. During the 1988 season, a John Deere 7000 Max-Emerge planter was used on both sets of plots; the following season, an International 800 Early Riser planter was used.

Both were six-row planters operated on 30 -in. centers. The John Deere planter was equipped with bubble coulters mounted to the planting unit and heavy duty down pressure springs, and carried about 200 gallons of water for additional weight. The coulters were operated about 1 in. deep in all tillage and planting systems. The International Harvester planter was a standard Early Riser model without coulters or additional weight. The planters were adjusted for proper soil-seed contact in moist soil and were not readjusted between treatments. Across each
Table 5. Cone-index measurements taken in the spring of 1990 after all tillage and planting operations had occurred.

\begin{tabular}{|c|c|c|c|c|c|c|c|c|}
\hline \multirow[b]{2}{*}{ Operation } & \multicolumn{8}{|c|}{ Depth, in. } \\
\hline & $0-2$ & $2-4$ & $4-6$ & $6-8$ & $8-10$ & $10-12$ & $12-14$ & $14-16$ \\
\hline & & & & \multicolumn{2}{|c|}{$\mathrm{lb} / \mathrm{sq}$ in. } & & & \\
\hline \multirow{2}{*}{$\begin{array}{l}\text { No-till } \\
\text { No-till w/ } \\
\quad \text { cultivation }\end{array}$} & $158 \ddagger$ & 222 & $291 \mathrm{ab} \dagger$ & $355 a$ & 385 & 394 & 388 & 378 \\
\hline & 149 & 247 & 323 & 3 & 392 & & & \\
\hline Disk & 134 & 218 & $314 a b$ & $388 \mathrm{a}$ & 428 & $\begin{array}{l}388 \\
419\end{array}$ & 368 & 358 \\
\hline Double-disk & 136 & 272 & $348 a$ & $375 a$ & 387 & 398 & 395 & $\begin{array}{l}403 \\
381\end{array}$ \\
\hline Chisel & 139 & 218 & $250 \mathrm{bc}$ & $333 a$ & 404 & 429 & 433 & 412 \\
\hline Plow & 148 & 172 & $175 \mathrm{c}$ & $230 \mathrm{~b}$ & 321 & 375 & 385 & 371 \\
\hline
\end{tabular}

$\dagger$ Means followed by the same letter in a column do not differ significantly at the $P=0.10$ level

$\ddagger$ Column without letters had no significant differences.

tillage plot, 20 observations of planter draft and speed were taken and these values were averaged for the analysis of variance (ANOVA).

Percentage of the soil surface covered with residue after planting was measured in June 1991, after $10 \mathrm{yr}$ of crop production and continuous tillage and planting system use. The line transect method using a $50-\mathrm{ft}$ measuring tape (Shelton et al., 1990) was used to measure the residue cover within each treatment.

Data analysis of yield, soil properties, and residue cover consisted of ANOVAs with Duncan's multiple range test to identify differences between treatments at the $10 \%$ level.

\section{RESULTS AND DISCUSSION}

Without exception, there were no differences in soybean yield among the tillage and planting system treatments for the first $3 \mathrm{yr}$ of yield measurement; and for grain sorghum there were no differences in yield among tillage and planting treatments in 1984 and 1985 (Table 2). In 1983, grain sorghum yield from the no-till with row-crop cultivation treatment was about $10 \%$ less than the other treatments. Reasons for this lower yield are not clear, especially when the other no-till treatment had the greatest yield. Row-crop cultivation may have caused excessive soil moisture loss in the previously untilled zone or may have pruned some shallow roots.

After $5 \mathrm{yr}$ of continuous use of the selected tillage and planting systems, several treatment differences in crop yield were measured (Table 3). From 1986 through 1990, either one or both of the no-till treatments had soybean yields that were greater than the traditional plow system. The 5-yr mean soybean yield from the no-till treatment was about $6 \%$ greater than the commonly used double-disk system and $11 \%$ greater than the traditional plow system.

In 1987 and 1989, the grain sorghum yield from the no-till treatment was greater than all of the other tillage and planting treatments except double-disk in 1987 and disk in 1989. The 5-yr mean grain sorghum yield from the no-till treatment was about $6 \%$ greater than the commonly used double-disk system and $9 \%$ greater than the traditional plow system.

For soybean, the yields from the no-till and no-till with cultivation treatments were not different (Tables 2 and 3 ). Since 1986, however, the grain sorghum yield from the 
Table 6. Power requirements for planters operating in selected tillage and planting systems.

\begin{tabular}{lcc}
\hline \multirow{2}{*}{$\begin{array}{c}\text { Tillage and } \\
\text { planting system }\end{array}$} & \multicolumn{2}{c}{ Planter, hp } \\
\cline { 2 - 3 } & $\begin{array}{c}\text { Int'l. Harvester } \\
\text { (1989 season) }\end{array}$ & $\begin{array}{c}\text { John Deere } \\
\text { (1988 season) }\end{array}$ \\
\hline No-till & $10.9 \mathrm{ab} \dagger$ & $10.0 \mathrm{ab}$ \\
No-till w/cultivation & $11.3 \mathrm{a}$ & $9.8 \mathrm{~b}$ \\
Disk & $10.2 \mathrm{~b}$ & $10.2 \mathrm{ab}$ \\
Double-disk & $10.2 \mathrm{~b}$ & $10.1 \mathrm{ab}$ \\
Chisel & $10.8 \mathrm{ab}$ & $10.6 \mathrm{ab}$ \\
Plow & $11.1 \mathrm{ab}$ & $10.8 \mathrm{a}$ \\
\hline
\end{tabular}

$\dagger$ Means followed by the same letter in a column do not differ significantly at the $P=0.10$ level.

no-till with cultivation treatment averaged 6 bu/acre (about $4 \%$ ) less than the no-till treatment. As observed in 1983 , row-crop cultivation may have caused excessive soil moisture loss in the previously untilled zone or may have pruned some shallow roots.

In general, the soil organic matter content in the upper 4 or 8 in. of soil was greater as the number of tillage and planting operations decreased (Table 4). Average organic matter content for the no-till treatment in the upper 4 in. was $3.3 \%$, compared with $2.9 \%$ for the plow treatment. Differences of organic matter were few among the other tillage and planting systems.

Cone-index values increased with depth, but there were few differences among tillage and planting systems (Table 5). Within the 4- to 6-in. depth increment, the double-disk treatment had greater resistance to penetration than the chisel and plow treatments. For this depth increment, the plow system had less resistance than all the other tillage and planting systems, except the chisel system. Within the 6- to 8-in. depth, the plow treatment also had the least resistance.

Average planter draft and drawbar power requirements for all the observations were $1,068 \mathrm{lb}$ and $10.5 \mathrm{hp}$, respectively. Previous crops influenced draft and power requirements, with an increase of about $1.5 \mathrm{hp}$ for the grain sorghum residue over the soybean residue. There was no consistent influence of tillage practice on planter power requirements (Table 6).

After planting, residue cover was greatest for no-till, and decreased as the number of tillage operations increased (Table 7). The minimum residue cover necessary for classification as conservation tillage is $30 \%$ after planting (CTIC, 1990). In the soybean residue, only the no-till treatment could be classified as conservation tillage. The residue levels measured in 1991, after $10 \mathrm{yr}$ of continuous use of the tillage and planting systems, were not appreciably different from those measured by Burr et al. (1987) in a short-term study. The residue cover value for the no-till soybean residue plot included some grain sorghum residue from 1989 production. Row-crop cultivation of the growing soybean in 1990 greatly reduced the amount of carryover grain sorghum residue measured in 1991.

In grain sorghum residue, only the no-till treatments had $30 \%$ or greater residue cover after planting (Table 7 ). Tillage and planting systems that included disking, chiseling, or plowing operations did not maintain the minimum residue cover $(30 \%)$, even though the average grain yield was $128 \mathrm{bu} /$ acre for these treatments, which is almost double the county average. Even in no-till, no
Table 7. Percentage residue cover remaining on the soil surface after planting after $10 \mathrm{yr}$ of continuous tillage and planting system use.

\begin{tabular}{lcc}
\hline $\begin{array}{c}\text { Tillage and } \\
\text { planting system }\end{array}$ & $\begin{array}{c}\text { Soybean } \\
\text { residue }\end{array}$ & $\begin{array}{c}\text { Grain sorghum } \\
\text { residue }\end{array}$ \\
\cline { 2 - 3 } & & \\
No-till & $36 \mathrm{a}^{\dagger}$ & $63 \mathrm{a}$ \\
No-till w/cultivation & $17 \mathrm{~b}$ & $54 \mathrm{~b}$ \\
Disk & $5 \mathrm{c}$ & $16 \mathrm{c}$ \\
Double-disk & $2 \mathrm{c}$ & $13 \mathrm{c}$ \\
Chisel & $3 \mathrm{c}$ & $15 \mathrm{c}$ \\
Plow & $0 \mathrm{c}$ & $3 \mathrm{~d}$ \\
\hline
\end{tabular}

† Means followed by the same letter in a column do not differ significantly at the $P=0.10$ level.

carryover of soybean residue was observed, which would have been counted in the grain sorghum residue plot.

Information gleaned from this research was presented in the annual area conservation tillage meetings and included in the proceedings of the meetings. The management practices and experience gathered demonstrated that producers had an excellent chance to succeed when using conservation tillage practices. According to Dickey et al. (1991b), about $80 \%$ of the respondents to the meeting evaluations indicated they planned to change their tillage practices as a result of the information presented.

\section{SUMMARY AND CONCLUSIONS}

No soybean yield differences were measured among the tillage and planting systems during the first $3 \mathrm{yr}$ of measurements following one rotation cycle. For grain sorghum, row-crop cultivation of no-till caused a yield decrease during the first year of measurement. Otherwise, there were no differences in grain sorghum yields for the first $3 \mathrm{yr}$ of yield measurements. For the last $5 \mathrm{yr}$, no-till tended to have the greatest yield for both crops. Thus, for the soil and conditions evaluated, no-till yields were as good as the other systems during early years, and were better after $5 \mathrm{yr}$ of continuous use. Row-crop cultivation in no-till did not result in any measurable yield increases. In grain sorghum, row-crop cultivation resulted in an average yield decrease of $6 \mathrm{bu} / \mathrm{acre}$.

After $10 \mathrm{yr}$, soil organic matter tended to be greatest for the continuous no-till treatment and lowest for the plow system. Resistance to penetration as measured by the cone penetrometer was not appreciably different for the tillage systems evaluated. The plow system had slightly less penetration resistance within the 4- to 8-in. depth, whereas, the double-disk system was slightly greater within the 2- to 4-in. depth. Overall, no-till penetration values were neither better nor worse than the other tillage and planting systems after $10 \mathrm{yr}$ of continuous use.

Draft and power requirements for planting in the selected tillage and planting systems were not different. Draft and power requirements were less in soybean residue covered areas than in grain sorghum residue, substantiating the general impression that a "loose, mellow surface" is created by soybean production.

The major difference among the tillage and planting systems studied was residue cover remaining after planting, which is a function of the number and type of tillage operations. No-till had the most residue cover, but similar to other studies of shorter term, there was no appreciable 
accumulation of residue over the years. During the last 5 $\mathrm{yr}$ of study, there was a tendency for greater yields to be associated with systems which retained more residue cover.

\section{REFERENCES}

Al-Darby, A.M., and B. Lowery. 1986. Evaluation of corn growth and productivity with three conservation tillage systems. Agron. J. 78:901-907.

American Society of Agricultural Engineers. 1983. Agricultural engineers yearbook of standards. Soil cone penetrometer. ASAE Standard S313.1. ASAE, St. Joseph, MI.

Bauder, J.W., G.W. Randall, and J.B. Swan. 1981. Continuous tillage: What it does to the soil. Crops Soils 34(3):15-17.

Burr, C.A., E.C. Dickey, and D.P. Shelton. 1987. Tillage system, row spacing, and variety influences on soybean residue cover. ASAE Paper no. 87-1006. ASAE, St. Joseph, MI.

Conservation Technology Information Center. 1990. 1990 National survey, conservation tillage practices. CTIC, West Lafayette, IN

Dick, W.A., and D.M. van Doren, Jr. 1985. Continuous tillage and rotation combinations effects on corn, soybean, and oat yields. Agron. J. 77:459-465.

Dickey, E.C., P.J. Jasa, and D.P. Shelton. 1991a. A conservation tillage educational program. J. Agron. Educ. 20:102-107.

Dickey, E.C., P.J. Jasa, D.P. Shelton, R.D Grisso, and K. Glewen. 1991b. Area conservation tillage meetings-a successful educational program. J. Agron. Educ. 20:115-119.

Dickey, E.C., T.R. Peterson, J.R. Gilley, and L.N. Mielke. 1983. Yield comparisons between continuous no-till and tillage rotations. Trans. ASAE 26:1682-1686.

Dickey, E.C., and A. Rider. 1980. Eastern Nebraska row-crop tillage systems. p 85-93. In Proc. Crop Production with Conservation in the 80s. ASAE, St. Joseph, MI.

Dickey, E.C., D.P. Shelton, P.J. Jasa, and T.R. Peterson. 1985. Soil erosion from tillage system used in soybean and corn residue. Trans. ASAE 28:1124-1129.

Doran, J.W., W.W. Wilhelm, and J.F. Power. 1984. Crop residue removal and soil productivity with no-till corn, sorghum and soybean. Soil Sci. Soc. Am. J. 48:640-645.
Erbach, D.C. 1982. Tillage for continuous corn and corn-soybean rotation. Trans. ASAE 25:906-911, 918.

Gilley, J.E., S.G. Finikner, and G.E. Varvel. 1986. Runoff and erosion as affected by sorghum and soybean residue. Trans. ASAE 29:1605-1610

Gregory, J.M. 1982. Soil cover prediction with various amounts and types of residue. Trans ASAE 25:1333-1337.

Griffith, D.R., and J.V. Mannering. 1985. Differences in crop yields as a function of tillage system, crop management and soil characteristics. p 47-58. In F.M. D'Itri (ed.) A systems approach to conservation tillage. Lewis Publ., Chelsea, MI.

Lackas, G.M., R.D. Grisso, M. Yasin, and L.L. Bashford. 1991. Portable data acquisition system for measuring energy requirements of soil-engaging implements. Comput. Electron. Agric. 5:285-296.

Laflen, J.M., W.C. Moldenhauer, and T.S. Colvin. 1980. Conservation tillage and soil erosion on continuously row-cropped land. p. 121-133. In Crop Production with Conservation in the 1980s. ASAE, St. Joseph, MI.

McGregor, K.C., and C.K. Mutchler. 1992. Soil loss from conservation tillage for sorghum. Trans. ASAE 35:1841-1845.

Mcisaac, G.F., J.C. Siemens, J.W. Hummel, and A.T. Tyrrell. 1990. Economic comparisons of six corn and soybean tillage systems, two soybean spacings on three farm sizes. Appl. Eng. Agric. 6:557-564.

Power, J.F., W.W. Wilhelm, and J.W. Doran. 1986. Crop residue effects on soil environment and dryland maize and soya production. Soil Tillage Res. 8:101-111.

Shelton, D.P., E.C. Dickey, P.J. Jasa, R. Knable, and S.R. Smydra. 1990 Using the line transect method to estimate residue cover. Univ. of Nebraska Coc.p. Ext. NebGuide G90-981.

Siemens, J.C., and W.R. Oschwald. 1978. Corn-soybean tillage systems: Erosion control, effects on crop production, costs. Trans. ASAE 21:293-302.

USDA-Soil Conservation Service. 1980. Soil survey of Lancaster County, Nebraska.

West, L.T., W.P. Miller, G.W. Langdale, R.R. Bruce, J.M. Laflen, and A.W. Thomas. 1991. Cropping systems effects on interrill soil loss in Georgia Piedmont. Soil Sci. Soc. Am. J. 55:460-466.

Wilhelm, W.W., J.W. Doran, and J.F. Power. 1986. Corn and soybean yield response to crop residue management under no-till production systems. Agron. J. 78:184-189. 


\title{
Long Term Tillage Effects on Grain Yield and Soil Properties in a Soybean/Grain Sorghum Rotation
}

\author{
Elbert C. Dickey, Paul J. Jasa, and Robert D. Grisso
}

\section{Research Question}

\section{Literature Summary}

\section{Study Description}

\section{Applied Question}


treatment was about $6 \%$ greater than the commonly used double-disk system and $11 \%$ greater than the traditional plow system. The 5 -yr mean grain sorghum yield from the no-till treatment was about $6 \%$ greater than the commonly used double-disk system and $9 \%$ greater than the traditional plow system.

For soybean, the yields from the no-till and no-till with cultivation treatments were not different. However, since 1986, the grain sorghum yield from the notill treatment has averaged 6 bu/acre higher (about 4\%) than the no-till with cultivation treatment. This difference was also observed in 1983 and was attributed to moisture stress associated with cultivation.

Soil organic matter tended to be greatest for the continuous no-till system and lowest for the plow system. The plow system had slightly less penetration resistance within the 4- to 8-in. depth, whereas, the double-disk system was slightly greater within the 2- to 4-in. depth. Draft and power requirements for planting in the selected tillage and planting systems were not different. The major difference among the tillage and planting systems was residue cover remaining after planting (Table 3). No-till had the most residue cover, but there was no appreciable accumulation of residue over the $10 \mathrm{yr}$ of continuous use of the tillage and planting systems.

Table 1. Operations for the tillage and planting systems evaluated.

\begin{tabular}{llccccc}
\hline & \multicolumn{5}{c}{ Tillage and planting system } \\
\cline { 2 - 7 } Operations & No-till & $\begin{array}{c}\text { No-till w/ } \\
\text { cultivation }\end{array}$ & Disk & $\begin{array}{c}\text { Double- } \\
\text { disk }\end{array}$ & Chisel & Plow \\
\hline Shred stalks (fall) $\dagger$ & & & & & $\mathrm{X}$ & $\mathrm{X}$ \\
$\begin{array}{l}\text { Fall moldboard plow } \\
\text { Fall chisel plow }\end{array}$ & & & & & & X \\
Knife apply NH ${ }_{3} \ddagger$ & $\mathrm{X}$ & $\mathrm{X}$ & $\mathrm{X}$ & $\mathrm{X}$ & $\mathrm{X}$ & $\mathrm{X}$ \\
Apply herbicide & $\mathrm{X}$ & $\mathrm{X}$ & $\mathrm{X}$ & $\mathrm{X}$ & $\mathrm{X}$ & $\mathrm{X}$ \\
Disk & & & & $\mathrm{X}$ & & $\mathrm{X}$ \\
Disk & $\mathrm{X}$ & $\mathrm{X}$ & $\mathrm{X}$ & $\mathrm{X}$ & $\mathrm{X}$ & $\mathrm{X}$ \\
Plant & $\mathrm{X}$ & $\mathrm{X}$ & $\mathrm{X}$ & $\mathrm{X}$ & $\mathrm{X}$ & $\mathrm{X}$ \\
Apply herbicide & & $\mathrm{X}$ & $\mathrm{X}$ & $\mathrm{X}$ & $\mathrm{X}$ & $\mathrm{X}$ \\
Crop cultivate & & & &
\end{tabular}

† Conducted on the grain sorghum residue only, before planting soybean. $\ddagger$ Conducted before planting grain sorghum only.
Table 2. Grain yield for the last 5 yr of measurement.

\begin{tabular}{|c|c|c|c|c|c|}
\hline \multirow{2}{*}{$\begin{array}{c}\text { Tillage and } \\
\text { planting system }\end{array}$} & \multicolumn{5}{|c|}{ Percentage of annual mean yield, $\%$} \\
\hline & 1986 & 1987 & 1988 & 1989 & 1990 \\
\hline \multicolumn{6}{|l|}{ Soybean } \\
\hline $\begin{array}{l}\text { No-till } \\
\text { No-till w/cultivation } \\
\text { Disk } \\
\text { Double-disk } \\
\text { Chisel } \\
\text { Plow }\end{array}$ & $\begin{array}{l}103 \mathrm{ab} \dagger \\
107 \mathrm{a} \\
98 \mathrm{~b} \\
97 \mathrm{~b} \\
99 \mathrm{~b} \\
97 \mathrm{~b}\end{array}$ & $\begin{array}{l}104 a \\
101 \mathrm{ab} \\
99 \mathrm{abc} \\
101 \mathrm{ab} \\
96 \mathrm{c} \\
98 \mathrm{bc}\end{array}$ & $\begin{array}{c}102 \mathrm{a} \\
105 \mathrm{ab} \\
101 \mathrm{ab} \\
98 \mathrm{~b} \\
100 \mathrm{ab} \\
94 \mathrm{~b}\end{array}$ & $\begin{array}{c}114 \mathrm{a} \\
105 \mathrm{ab} \\
99 \mathrm{bc} \\
99 \mathrm{bc} \\
94 \mathrm{bc} \\
89 \mathrm{c}\end{array}$ & $\begin{array}{r}102 a \\
103 a \\
103 a \\
99 a \\
102 a \\
91 b\end{array}$ \\
\hline Mean yield, bu/acre & 53 & 51 & 36 & 43 & 41 \\
\hline \multicolumn{6}{|l|}{ Grain sorghum } \\
\hline $\begin{array}{l}\text { No-till } \\
\text { No-till w/cultivation } \\
\text { Disk } \\
\text { Double-disk } \\
\text { Chisel } \\
\text { Plow }\end{array}$ & $\begin{array}{c}100 \ddagger \\
100 \\
98 \\
99 \\
100 \\
102\end{array}$ & $\begin{array}{c}105 \mathrm{a} \\
100 \mathrm{~b} \\
97 \mathrm{~b} \\
101 \mathrm{ab} \\
99 \mathrm{~b} \\
99 \mathrm{~b}\end{array}$ & $\begin{array}{r}107 \\
102 \\
96 \\
100 \\
100 \\
96\end{array}$ & $\begin{array}{l}106 \mathrm{a} \\
100 \mathrm{bc} \\
103 \mathrm{ab} \\
96 \mathrm{~cd} \\
101 \mathrm{bc} \\
93 \mathrm{~d}\end{array}$ & $\begin{array}{r}107 a \\
105 a \\
101 a \\
101 a \\
99 a \\
89 b\end{array}$ \\
\hline Mean yield, bu/acre & 149 & 128 & 134 & 106 & 136 \\
\hline
\end{tabular}

Table 3. Percentage residue cover remaining on the soil surface after planting after $10 \mathrm{yr}$ of continuous tillage and planting system use.

\begin{tabular}{lcc}
\hline \multicolumn{1}{c}{$\begin{array}{c}\text { Tillage and } \\
\text { planting system }\end{array}$} & $\begin{array}{c}\text { Soybean } \\
\text { residue }\end{array}$ & $\begin{array}{c}\text { Grain sorghum } \\
\text { residue }\end{array}$ \\
\cline { 2 - 3 } & & $\%$ \\
No-till & $36 \mathrm{a} \dagger$ & $63 \mathrm{a}$ \\
No-till w/cultivation & $17 \mathrm{~b}$ & $54 \mathrm{~b}$ \\
Disk & $5 \mathrm{c}$ & $16 \mathrm{c}$ \\
Double-disk & $2 \mathrm{c}$ & $13 \mathrm{c}$ \\
Chisel & $3 \mathrm{c}$ & $15 \mathrm{c}$ \\
Plow & $0 \mathrm{c}$ & $3 \mathrm{~d}$ \\
\hline
\end{tabular}

$\dagger$ Means followed by the same letter in a column do not differ significantly at the $P=0.10$ level. 